\title{
KATA “ALLAH” DALAM AL-QURAN DAN ALKITAB Kajian Terhadap Pelarangan Menggunakan Kata “Allah" Bagi Selain Muslim
}

\author{
Zainal Arifin \\ Fakultas Dakwah Institut Agama Islam Negeri (IAIN) \\ Sumtara Utara \\ e-mail: arifbillah25@gmail.com.
}

\begin{abstract}
This study appears due MUIS Malaysiabanthe use of the word "Allah" for the citizensis not Islam. This study examined for the purposes of the establishment of religious tolerance based on the understanding of religion. This paperseeks to explain that the word "Allah" containedin the Qur'anand the Bible, by limiting the study of the Qur'an andthe Bible, to formulate the concept of "Allah" who became God for Muslims. This study found that the word "Allah" though not derived from Arabic, heeventually became part of the Arabic language of the Koran. Healso became the name of God for Muslims. Furthermore, the authors found that in addition toMuslims, Christiansand Jewsmay usethe word"Allah" toindicatetheirGod. When a Christian used to indicate the name of Jesus, it is alsoallowedas a form of tolerance. Asthe infidelsQuraishmentionsculptureasa means of worshipingGod.
\end{abstract}

Abstrak: Kajian ini muncul akibat pelarangan MUIS Malaysia dalam penggunaan kata "Allah" bagi warga bukan Islam. Kajian ini dikaji untuk keperluan tegaknya toleransi beragama berdasarkan pemahaman agama. Tulisan ini berupaya menjelaskan bahwa kata "Allah" tertuang dalam Al-Quran dan Alkitab, dengan membatasi telaah pada Al-Quran dan Alkitab, merumuskan konsep "Allah" yang menjadi Tuhan bagi Muslim. Penelitian ini menemukan bahwa kata "Allah" walau bukan berasal dari bahasa Arab, ia akhirnya menjadi bagian dari bahasa Quran yang Arab. Ia juga menjadi nama Tuhan bagi 
ZAINAL ARIFIN: Kata"Allah" dalam Al-Quran dan Alkitab

umat Islam. Lebih jauh lagi, penulis menemukan bahwa selain Muslim, umat Nasrani dan Yahudi boleh menggunakan kata "Allah" untuk menunjukkan Tuhan mereka. Bila seorang Kristiani menggunakannya untuk menunjukkan nama Yesus, itu juga dibolehkan sebagai wujud toleransi. Sebagaimana kaum kafir Quraisy menyebutkan patung sebagai sarana menyembah Allah.

Keywords: Allah, Al-Quran, Alkitab, God, Islam, Kristen.

\section{A. Pendahuluan}

Latar Belakang masalah dari kajian ini adalah Pemerintah Malaysia pada 10 Desember 2007 mengeluarkan kebijakan bahwa kata Allah tidak boleh digunakan oleh agama selain Islam, dan pelarangan Majelis Agama Islam Selangor (Mais)menggunakan kata Allah bagi selain Muslim untuk menunjukkan Tuhan mereka. Pelarangan Mais ini telah final setelah pengadilan Malaysia memutuskan pelarangan penggunaan kata "ALLAH" bagi koran katolik The Herald.

Menyusul pelarangan tersebut, negara bagian Selangor, Malaysia, melarang lagu penyanyi pop Indonesia Agnes Monica berjudul "Allah Peduli" karena menggunakan kata Allah dalam lirik lagunya untuk menggambarkan Nabi Isa. Larangan itu juga dikenakan kepada siapa pun yang menyanyikan lagu itu di negara bagian Selangor. Jika terbukti bersalah, maka tertuduh akan didenda 1.000 ringgit Malaysia (Rp3,2 juta).

Dari latar belakang masalah di atas timbul satu persoalan yang akan dikaji dalam tulisan ini, yaitu: apakah benar selain Muslim tidak boleh menyebutkan "Allah" sebagai sebutan untuk menyebutkan Tuhan mereka?

Kajian ini adalah kajian perpustakaan dengan menggunakan metodologi perbandingan antara kitab suci dan Tafsir Tematik. Maksud Tafsir Tematik dalam kajian ini adalah menghimpun ayat- 
ayat yang terkait dengan tema dan topik tertentu dan menganalisanya secara mendalam sampai pada akhirnya dapat disimpulkan pandangan atau wawasan Al-Quran menyangkut tema tersebut. ${ }^{1}$

Sumber masalah yang utama dari kajian ini terletak pada kata "Allah" itu sendiri. Pertama, apakah kata "Allah" itu berasal dari bahasa Arab atau bukan? Kedua, apakah kata "Allah" itu berupa nama atau istiqaq?

Tujuan artikel ini ini untuk keperluan tegaknya toleransi beragama berdasarkan pemahaman agama. Baik agama Islam atau pun agama Nasrani.

\section{B. Tentang 'Allah'}

\section{Arti kata "Allah"}

Perkataan "Allah dapat diartikan oleh Thabari dengan ya'lahuhu kullu syai wa ya'buduhu kullu khaliq, Zat yang dituhankan oleh segala sesuatu dan disembah oleh setiap makhluk. ${ }^{2}$ Menurut alGhazali pemikir Islam beraliran Sunni, Allah adalah nama untuk zat yang ada dalam arti yang sebenarnya yang memiliki seluruh sifatsifat Ilahiyah, dan berperilaku dengan perilaku Rubūbiyah, yang khas dengan wujud hakiki. Semua yang wujud/ada selain-Nya tidak layak untuk dinyatakan sebagai wujud secara zat-Nya. ${ }^{3}$ Menurut Zamakhsari yang beraliran Muktazilah Allah adalah Tuhan yang disembah secara benar. ${ }^{4}$ Menurut Said haji Ibrahim pemikir Islam Malaysia Allah ialah lafaz Jalalah atau lafaz yang Maha Besar dan Maha Agung. Iaitu nama Zat Ilahi yang Maha Suci lagi Maha Mulia yang wajib ada selama-lamanya dan yang berhak memiliki alam ini, dan juga yang layak menerima pujian dan sanjungan. ${ }^{5}$

Dari beberapa definisi ini semua sepakat bahwa kata "Allah" adalah lafaz jalalah atau lafaz yang Maha Besar dan Maha Agung. 
ZAINAL ARIFIN: Kata"Allah" dalam Al-Quran dan Alkitab

Yaitu nama Zat Ilahi yang layak disembah. Namun apakah kata "Allah" itu berasal dari Bahasa Arab atau bukan?

\section{Kata "Allah" Bukan Berasal Dari Bahasa Arab}

Berdasarkan Al-Quran bahwa perkataan "Allah" bukan berasal dari bahasa asli kitab suci Al-Quran. Dalam perkataan lain, kata "Allah" telah dikenal oleh kaum Quraisy sebelum Al-Quran diturunkan. Mereka menyebutkan tuhan-tuhan mereka dengan sebutan Ālihah. Atau kata Allah berasal dari bahasa asing yaitu Alohim. Pendapat ini ditemukan di dalam Lisan al-Arab, tepatnya dalam hadis yang diriwayatkan oleh Wuhaib ibn al-Ward. ${ }^{6}$

Dari sejarah kita dapat melihat bahwa 'Allah' di kalangan bangsa dan bahasa Arab tidak lain menunjuk pada 'El' Semit' yang sama, ini dijelaskan dalam buku-buku teologi Kristen maupun Ensiklopedia Islam bahwa setidaknya bangsa Arab mewarisi tiga jalur nenek moyang yang semuanya mengenal 'El Abraham' yaitu sebagai keturunan Sem, Yoktan (keturunan Eber), dan Adnan (keturunan Ismael anak Abraham).

Bila penulis teliti kajian ini berdasarkan pada penelusuran kata "Allah" di dalam kitab suci, maka akan ditemukan sebagai berikut: Perkataan "Allah" dalam Al-Quran diulang sebanyak dua ribu enam ratus sembilan puluh tujuh (2.697) kali.7 Di dalam Alkitab versi Indonesia, perkataan "Allah" terdapat sebanyak tiga ribu tujuh ratus tujuh puluh tujuh (3.777) ayat. Dua ribu empat ratus empat puluh dua (2.442) terdapat di Perjanjian Lama (PL) dan seribu tiga ratus tiga puluh lima (1.335) ayat di dalam Perjanjian Baru (PB). ${ }^{8}$ Perkataan "Allah" juga digunakan dalam Alkitab versi Bahasa Arab, ${ }^{9}$ tetapi untuk bahasa Inggeris digunakan perkataan "God".10

Berdasarkan pada Al-Quran, sejarah dan Alkitab (PL+PB) disimpulkan bahwa kata "Allah" bukan berasal dari bahasa Arab, tapi berasal dari bahasa asing yang diubah menjadi bahasa Arab, hingga 
akhirnya menjadi bagian yang tidak terpisahkan dengan bahasa alQuran yang Arab. Di sisi lain, bahwa Alkitab Nasrani baik Perjanjian Lama atau pun Perjanjian Baru telah mengenal nama Allah untuk sebagai nama dari Tuhan yang disembah. Contohnya dalam Alkitab Kristen Perjanjian Lama dituliskan kata Allah secara nyata: "Pada mulanya Allah menciptakan langit dan bumi.Bumi belum berbentuk dan kosong; gelap gulita menutupi samudera raya, dan Roh Allah melayang-layang di atas permukaan air.Berfirmanlah Allah: "Jadilah terang." Lalu terang itu jadi."11

Dari penjelasan di atas, penulis lebih cenderung pada pendapat bahwa kata "Allah" bukan berasal dari bahasa Arab, tapi berasal dari bahasa asing yang diubah menjadi bahasa Arab. Ini beranjak dari pernyataan Al-Quran sendiri bahwa para nabi menyebutkan Tuhan yang mereka sembah adalah Tuhan yang bernama "Allah". Diketahui bersama bahwa hampir seluruh nabi diutus Allah kepada kaum Bani Israel yang menggunakan bahasa Ibrani dan kemudian Suryani, atau bukan menggunakan bahasa Arab. Kemudian saat Nabi Muhammad diutus, kaum kafir Quraisy telah mengenal Allah sebagai tuhan dari segala tuhan berhala yang mereka sembah. Hal ini ditegaskan kaum kafir Mekkah saat ditanya alasan penyembahan tuhan berhala, yang dijawab mereka untuk mendekatkan kepada Allah. ${ }^{12}$

\section{Kata “Allah" Itu Berupa Kata Serapan bukan Nama}

Apakah kata "Allah" itu berupa nama atau serapan? Tidak jauh berbeda dengan permasalahan pertama, pada permasalahan kedua ini juga terdapat dua pendapat besar. Pertama, menurut al-Razi ${ }^{13}$ dan al-Ghazali14 bahwa lafaz "Allah" adalah nama Allah Swt yang tidak memiliki perkataan kata terbitan. Sementara pendapat kedua yang dianut oleh al-Zamakhsari, ${ }^{15}$ Ibn al-Qayyim ${ }^{16}$ dan Ibn Manzur ${ }^{17}$ bahwa perkataan "Allah" berasal dari perkataan al-Ilah, dihapuskan hamzah dan diganti dengan alif lam ta'rif. Alif dan lam yang dimasukkan pada perkataan Ilah berfungsi menunjukkan bahwa 
ZAINAL ARIFIN: Kata"Allah" dalam Al-Quran dan Alkitab

perkataan yang dimasukkan itu (perkataan Ilah) merupakan sesuatu yang telah dikenal dalam benak. Kedua-dua huruf tambahan itu menjadikan kata yang diletak menjadi makrifat. Selanjutnya dengan alasan mempermudah, hamzah yang berada antara dua lam yang dibaca (i) pada kata Al-Ilah tidak dibaca lagi sehingga berbunyi "Allah".

Menurut aliran yang berpendapat "Allah memiliki kata terbitan," maka perkataan itu dapat diartikan ke dalam bahasa dunia. Dalam bahasa Indonesia dan Malaysia, kedua-duanya (Allah dan Ilah) dapat diterjemahkan dengan tuhan, tetapi cara penulisannya dibedakan. Sifat am (Ilah) ditulis dengan huruf kecil "tuhan", dan yang bermakna khusus (Allah) ditulis dengan huruf besar "Tuhan." Sebagaimana dalam bahasa Inggeris menjadi "God" dan "god". Menurut pendapat bahwa "Allah nama yang tidak memiliki kata terbitan," maka ia tidak dapat diartikan, ia tetap menjadi "Allah".

Berdasarkan pada pendapat bahwa perkataan "Allah" untuk menunjukkan nama "Tuhan", maka ditemukan Alkitab Kristian versi bahasa Indonesia dan Arab tetap menggunakan perkataan "Allah", sedangkan Alkitab versi bahasa Inggeris menggunakan perkataan "God" sebagai ganti dari perkataan "Allah". Sedangkan terjemahan makna al-Quran versi bahasa Indonesia dan Malaysia serta Inggeris sampai saat ini masih tetap menggunakan perkataan "Allah" bukan "Tuhan" atau "God". Penulis lebih sependapat dengan pernyataan bahwa "Allah" nama yang tidak memiliki kata terbitan, dengan tidak menutup pemahaman untuk lebih mengetahui kata terbitan darinya sebagai khazanah yang dapat memperkaya keilmuan dan meneguhkan keimanan.

Menurut kamus Ibn Manzur dan Ibn Faris, di antara makna dari perkataan "Ilah" yang darinya terbentuk perkataan "Allah", berakar dari perkataan al-Ilah yang bermakna (1) Ma'bud/Yang Disembah, ${ }^{18}$ (2) berakar dari perkataan al-Ilahwilah yang bermakna mengharap. Yuwalluhuna ilahi artinya merintih dan mengharap 
kepada-Nya. (3)berakar dari perkataan al-Ilah yang bermakna ibadah atau penyembahan. ${ }^{19}$ Bahwa perkataan tersebut berakar daripada perkataan "alaha" dalam arti mengherankan atau "menakjubkan" karena segala perbuatan/ciptaan-Nya menakjubkan atau kerana bila dibahaskan hakikatnya akan menghairankan akibat ketidaktahuan makhluk tentang hakikat Zat Yang Maha Agung itu; atau perkataan "Allah" terambil daripada akar perkataan "aliha ya'lahu" yang berarti "tenang", karena hati menjadi tenang bersamaNya, atau dalam arti "menuju" dan "bermohon", karena harapan seluruh makhluk tertuju kepada-Nya dan kepada-Nya jua makhluk bermohon. ${ }^{20}$

Memang setiap yang dipertuhankan pasti disembah, dan kepadanya tertuju harapan dan permohonan, lagi menakjubkan ciptaannya, tetapi apakah itu berarti bahwa perkataan "Ilah" dan juga "Allah" secara harfiah bermakna demikian? Apakah Al-Quran menggunakannya untuk makna "yang disembah"? Para ulama yang mengartikan Ilah dengan "yang disembah" menegaskan bahwa Ilah adalah segala sesuatu yang disembah, sama ada penyembahan itu tidak dibenarkan oleh akidah Islam; separti terhadap matahari, bintang, bulan, manusia atau berhala; mahupun yang dibenarkan dan diperintahkan oleh Islam, yakni Zat yang wajib wujud-Nya yakni Allah. Karena itu, jika seorang muslim mengucapkan "la ilaha illa Allah" maka dia telah menafikan segala tuhan kecuali Tuhan yang nama-Nya, Allah,"21 atau bahwa Ilah adalah "Pencipta, Pengatur, Penguasa alam raya, yang di dalam genggaman tangan-Nya segala sesuatu".22

Dengan demikian jelaslah bahwa Allah adalah berasal dari makna serapan yang kemudian berubah menjadi nama. Ia sama dengan kata Muhammad yang artinya dipuji dan memuji, kemudian berubah menjadi nama yang ditujukan kepada nabi terakhir yang dipercayai umat Islam. 
ZAINAL ARIFIN: Kata"Allah" dalam Al-Quran dan Alkitab

\section{4. "Allah" Tuhan Para Nabi dan Kaum Musyrik}

Dari keterangan di atas dapat lebih ditegaskan bahwa ilah yang merupakan akar kata dari Allah digunakan untuk menunjukkan kata "Tuhan" yang hak dan batil, termasuk Tuhan umat Kristen. Bila mengikuti paham yang beraliran kata "Allah" berasal dari kata ilah maka Tuhan umat Kristen dapat juga disebutkan dengan Allah, begitu juga dengan Tuhan utama kaum kafir Mekah.

Dari keterangan Alkitab (PL+PB) dan Al-Quran di atas jelas terlihat bahwa sebagai oknum dengan namanya "Allah" bagi umat Islam adalah sama dengan Tuhan Yahudi dan Kristen. Kesamaan nama dan kesamaan pesan di antara para nabi, karena semua nabi bersumber dari satu Tuhan, yaitu Allah. ${ }^{23}$

Bila kemudian terdapat perbedaan di antara agama Islam dan Kristen dalam pemahaman Allah sebagai Tuhan yang layak disembah, maka hal itu bermula dari kelahiran Isa tanpa ayah. Umat Islam memahami Allah sebagai Tuhan yang Maha Esa, maka sebenarnya umat Kristen pun memahami Allah sebagai Tuhan yang Maha Esa. Namun umat Kristen mengakui keesaan Allah tidak menutup kemungkinan dia berstatus tiga, sehingga keyakinan ini dikenal dengan Tritunggal yang artinya tiga tapi satu, atau satu tapi tiga.

Menariknya di dalam Perjanjian Lama ajaran monoteisme atau tauhid merupakan ajaran utama, "Dengarlah, hai orang Israel: Tuhan itu Allah kita, Tuhan itu esa! Kasihilah Tuhan, Allahmu, dengan segenap hatimu dan dengan segenap jiwamu dan dengan segenap kekuatanmu."24 Sementara Nabi Isa menegaskan bahwa dia datang tidak menghapuskan Perjanjian Lama tapi datang untuk melengkapinya dengan Perjanjian Baru. ${ }^{25}$ Bila dalam Perjanjian Lama tauhid dan tanzih merupakan ajaran utama, maka dalam Perjanjian Baru pun ditemukan pernyataan Allah Swt itu satu. 
"Jawab Yesus: 'Hukum yang terutama ialah: Dengarlah, hai orang Israel, Tuhan Allah kita, Tuhan itu esa."26

Pada Alkitab tidak ditemukan perkataan "Tri tunggal atau Tiga Tuhan" dengan tegas, yang ada hanyalah penafsiran pendeta terhadap Alkitab, selepas Konsili Nicea dan didefinisikan lebih lengkap dalam Kredo Athanasia. Kredo yang memakai namanya berbunyi: "Kami menyembah satu Allah dalam Tri tunggal... sang Bapa adalah Allah, sang Anak adalah Allah, dan Roh Kudus adalah Allah; namun mereka bukan tiga allah, tetapi satu Allah." 27

Tri tunggal ini adalah doktrin dasar agama Kristen mengenai tiga pribadi asas Tuhan. Pribadi tersebut adalah Tuhan Bapa, Tuhan Anak dan Tuhan Roh Kudus.. ${ }^{28}$ Sebahagian dari pemeluk Kristen ada yang menolak doktrin Tri tunggal, atau sekadar menganggapnya suatu hal yang tidak begitu penting. Seseorang atau satu komunitas yang berada pada posisi ini tidak menyebut diri mereka sebagai "Anti Tri tunggal", namun bervariasi sesuai alasan mereka menolak Tri tunggal dan sesuai bagaimana mereka menjelaskan tentang Tuhan. ${ }^{29}$

Menurut penulis, berasaskan al-Quran dan Alkitab serta alasan-alasan di atas, bahwa selain muslim; tepatnya musyrik dan Ahli Kitab juga menggunakan istilah "Allah" sebagai sebutan untuk "Tuhan" mereka.30 Walau pun kemudian antara penganut al-Quran dan penganut Alkitab (Kristen) terdapat perbedaan pemahaman tentang ketuhanan Yesus dan Roh Kudus. Bahkan di antara sesama Kristen itu sendiri terdapat perbedaan yang mendasar tentang ketuhanan keduanya.

Lebih jauh lagi hubungan harmonis antara Islam dan Ahli Kitab yang memiliki satu Tuhan yaitu "Allah" dipertegas dengan dibolehkannya muslim untuk menikah dengan wanita kitabiyah dan memakan hasil sembelihan ahli kitab. Ulama berbeda pendapat tentang boleh tidaknya muslim menikah dengan wanita kitabiyah. 
ZAINAL ARIFIN: Kata"Allah" dalam Al-Quran dan Alkitab

Hal ini berdasarkan pada al-Baqarah [2]: 221 yang melarang menikah dengan musyrik dan musyrikah dengan al-Maidah [5]: 5 yang membolehkan menikah dengan kitabiyah. Walaupun ulama berbeda pendapat tapi penulis berdasarkan buku Tafsir Tematik: Hubungan Antar Umat Beragama berkesimpulan bahwa kehalalan dan kebolehan itu merupakan wujud toleransi Islam dalam pergaulan bermasyarakat dengan pemeluk agama lain. ${ }^{31}$ Toleransi yang tetap dalam bingkai menjaga agama merupakan syarat bagi kebolehan pernikahan tersebut.

Satu hal yang menarik, bahwa kesamaan Tuhan "Allah" di antara ahli kitab (Yahudi dan Nasrani) dengan Islam membuat hubungan yang lebih harmonis di antara umat Islam dengan mereka dengan diberikan kelonggaran dalam pernikahan dan sembelihan, maka ini tidak berlaku bagi kaum musyrik Mekkah yang juga mengaku bertuhankan "Allah." Alasannya, menurut penulis, karena di samping kesamaan dalam ketuhanan "Allah", terdapat juga kesamaan dalam keimanan kepada kitab suci, malaikat, para nabi. Keimanan ini diyakini oleh Ahli Kitab (Yahudi dan Nasrani) dan tidak diimani oleh kaum musyrik.

\section{Mengubah kata "Allah" menjadi "God"}

Ada sebagian orang-orang Kristen yang meyakini bahwa nama "Allah" sebagai nama "dewa bulan"32, dan melihat realita di dalam Alkitab menggunakan istilah Allah maka mereka melakukan perubahan /penggantian nama Allah diganti dengan nama "God" inilah yang terjadi dalam Alkitab terjemahan versi Inggris.

Alkitab Perjanjian Lama, dalam bahasa Indonesia terlihat jelas ungkapan kata "Allah". Contohnya: "Pada mulanya Allah menciptakan langit dan bumi."33 Bandingkan dengan Alkitab King James Version "In the beginning God created the heaven and the earth. "34 Hal senada ditemukan dalam Alkitab dalam versi Contemporery English Version "In the beginning God created the heavens and the 
earth." Begitu juga dengan Alkitab dalam versi Today's English Version "In the beginning, when God created the universe."

Hal senada dengan Alkitab Perjanjian Baru. Contohnya: Sesungguhnya anak dara itu akan mengandung dan beranakkan seorang anak laki-laki, dan disebut orang namanya: Immanuel, yang diterjemahkan artinya 'Allahbeserta kita.'35 Sementara dalam Alkitab King Jemes Version berbunyi "Behold, a virgin shall be with child, and shall bring forth a son, and they shall call his name Emmanuel, which being interpreted is, God with us."36 Contemporery English Version berbunyi: "God is with us." Today's English Version berbunyi: "God is with us."

Dari ketiga terjemahan Alkitab dalam bahasa Inggris -baik Perjanjian Lama ataupun Perjanjian Baru- walaupun berbeda terjemahannya, tapi semua sepakat bahwa kata "Allah" yang ditemukan dalam Alkitab versi Indonesia dan Arab tidak diabadikan dalam wujud kata "Allah", tapi dirubah menjadi kata "God". Walau pun di awal penulis dapat memahami dan dapat mengerti bahwa kata "Allah" dapat diartikan menjadi "Tuhan" atau "God" dalam bahasa Indonesia dan Inggris, tapi tetap saja, pola pikir bahwa "Allah" adalah dewa bulan atau lebih dari itu "sebagai wujud dari anti Arab" maka penerjemah bahasa Inggris lebih senang menerjemahkan kata "Allah" menjadi "God".

Satu hal yang menarik, hal itu tidak dilakukan oleh penerjemah Alkitab versi Indonesia dan Arab. Mereka tetap mempertahankan kata "Allah" baik dalam bahasa Indonesia dan Arab. Menurut penulis hal ini dilakukan karena istilah "Allah" telah menjadi milik bersama antara Muslim Indonesia dan umat Nasrani Indonesia, atau Muslim Arab dengan umat Nasrani Arab. Tanpa ada rasa kecemburuan atau sentimen dalam beragama.

Bahwa ajaran/konsep mengenai 'Allah' (El) itu kemudian merosot dan makin tidak mendekati hakikat yang di'nama'kan dan 
ZAINAL ARIFIN: Kata"Allah" dalam Al-Quran dan Alkitab

ditujukan kepada pribadi lain seperti yang terjadi pada jalur Ishak (Anak Lembu Emas disebut 'allah' dengan "a" huruf kecil, dalam bahasa Indonesia Terjemahan Baru) ${ }^{37}$ maupun jalur Ismael (masa jahiliah, dewa berhala disebut 'Allah') ${ }^{38}$, tentu tidak mengurangi hakikat nama itu sendiri sebagai menunjuk kepada "Allah sebagai Tuhan yang layak disembah bagi penganut kitab samawi. Ini dapat diyakini bahwa 'Allah' Yahudi, Kristen dan Islam terdapat kesamaan, sehingga mereka disebut dengan "Ahli Kitab" yang dapat diartikan dengan saudara dekat dalam beragama.

\section{6. "Allah" Nama Tuhan umat Islam}

Namun kemudian, bila disebutkan kata "Allah" maka ucapan itu mengarah kepada Tuhan umat Islam. Ini sama dengan kata "salat" dan "muslim" dalam al-Quran yang berarti "doa" dan "kepasrahan" yang dilakukan oleh umat nabi manapun. Contohnya, dalam bahasa al-Quran ditemukan bahwa Nabi Ibrahim melakukan "salat" dan berstatus "muslim", tapi ketika diartikan secara istilah, maka kata "salat" ditujukan pemahamannya kepada "salat yang dilakukan muslim sehari lima kali dengan cara tertentu dimulai dengan takbir dan ditutup dengan salam."

Untuk itu kamus-kamus dalam bahasa Inggeris mendefinisikan "Allah sebagai name of Godamong Muslims and among Arab of all faiths. ${ }^{39}$ Artinya, Allah adalah nama Tuhan di antara umat Islam atau di antara bangsa Arab atas semua keyakinan. Hans Wehr, yang merupakan kamus Arab-Inggris mendefinisikan Allah adalah Allah, God (as teh One and Only. ${ }^{40}$ Artinya, Allah adalah Allah atau Tuhan yang Maha Esa dan Satu-Satunya.

Definisi dalam bahasa Indonesia dapat dilihat dalam Ensiklopedi Nasional Indonesia bahwa: "Allah adalah Tuhan, pencipta alam raya termasuk segala isinya".41 Dapat juga dilihat dalam Kamus Purwadarminta yang mendefinisikan Allah dengan Roh Yang Mahasempurna yang menciptakan alam semesta. ${ }^{42}$ Artinya, 
para penulis kamus baik dalam bahasa Inggris ataupun Indonesia dan Arab mengakui ke-khasan nama Allah dalam penggunaannya di kalangan agama Islam sebagai salah satu artinya. Namun dalam arti yang lain, jelas memberikan pengertian yang lebih luas, sehingga mencakup Tuhan agama apapun di semenanjung Arab dan di Asia Tenggara. Berdasarkan definisi Hans Wehr di atas, terlihat bahwa dia menafikan kata "Allah" sebagai Tuhan dalam pengertian "Yesus". Alasannya, timbulnya dua Tuhan.

\section{Apa yang Tergambar tentang "Allah" bukan Allah}

Menurut Wajdi, al-Quran telah sampai pada pembuktian klimaks tesis akan keberadaan Allah sebagai Tuhan. Kalau tiada Tuhan, siapa yang akan menciptakan langit dan bumi. ${ }^{43}$ Manusia secara fitrah dapat mengenal Tuhan. ${ }^{44}$ Berkata rasul-rasul mereka: "Apakah ada keraguan terhadap Allah, Pencipta langit dan bumi?"45

Tapi, adakah manusia mengenal hakikat zat Allah? Manusia tidak dapat mengenal hakikat Allah, karena tidak ada yang mengenal hakikat Allah kecuali Allah, sebagaimana tidak ada yang mengenal hakikat nabi kecuali nabi, dan tidak ada yang mengenal hakikat surga dan neraka kecuali setelah wafat dan masuk ke dalam surga atau neraka. Puncak dari orang yang mengenal Allah adalah ketidakmampuan mereka untuk mengenal hakikat Allah. ${ }^{46}$ Tidak ada sesuatu pun yang serupa dengan Dia, dan Dia-lah yang Maha mendengar dan melihat. ${ }^{47}$

Jika demikian 'apa pun yang tergambar dalam benak atau imaginasi siapa pun tentang Allah, maka Allah tidak demikian'. Dengan membaca dan menyadari makna ayat ini, luluh semua gambaran yang dapat dijangkau oleh indera dan imajinasi manusia tentang zat Yang Maha Sempurna itu. ${ }^{48}$

Manusia juga tidak dapat mengenal hakikat sifat dan nama Allah kecuali dengan perumpamaan. Contohnya, kuasa Tuhan adalah sifat, selama hamba bertambah ilmu pengetahuan tentang perincian 
ZAINAL ARIFIN: Kata"Allah" dalam Al-Quran dan Alkitab

kuasa Tuhan di alam raya ini, maka pengetahuannya tentang kuasa Tuhan bertambah banyak. Ini karena buah menunjukkan pada pohon, tetapi karena maklumat itu tiada nihayah dan akhir, di samping ia bertingkat, maka kita dapat mengenali tingkatan manusia di lautan makrifat Allah yang tiada bertepi itu. ${ }^{49}$

Walaupun penulis telah sampai pada titik "tidak ada yang dapat mengenal Allah kecuali Allah" namun pernyataan "saya tidak mengenal kecuali Allah" juga benar dan dapat diterima, karena tidak ada di alam yang wujud ini kecuali Allah dan segala perbuatan-Nya. ${ }^{50}$ Kedua-dua pernyataan ini benar, karena dua sudut pandang yang berbeda. Pertama, dilihat dari sudut pandang zat, sifat dan namaNya; kedua, dilihat dari wujud makhluk yang merupakan hasil dari ciptaan Allah Swt, sama ada alam raya, manusia atau pun sejarah kehidupan. ${ }^{51}$

\section{PENUTUP}

Dengan demikian kata "Allah" dalam kitab suci: al-Quran dan Alkitab dapat diartikan dengan Tuhan yang disembah. Kedua kitab suci ini sampai sekarang masih menggunakan kata "Allah" untuk menunjukkan kata "Tuhan" bagi masing-masing pengikutnya di Indonesia dan di Arab, tapi tidak untuk pengguna Alkitab berbahasa Inggris. Ini menegaskan bahwa selain Muslim, terutama umat Nasrani dan Yahudi boleh dan dibenarkan menggunakan kata "Allah" untuk menunjukkan kata 'Tuhan' bagi mereka. Umat Islam harus menghormati kedua agama ini dengan kesamaan nama "Tuhan" yang mereka dan muslim sembah. Untuk itu mereka disebut dengan golongan Ahli Kitab. Ahli Kitab yang memiliki keistimewaan lebih dari kaum kafir lainnya, di antaranya keistimewaan dalam menikahi wanita kitabiyah dan memakan hasil sembelihan mereka.

Bila muncul kemudian fatwa MUIS Selangor di Malaysia, ini lebih karena pemahaman selanjutnya bahwa kata "Allah" adalah nama Tuhan yang disembah oleh umat Islam. Sebagai satu nama 
yang perlu dihormati, maka umat Islam menjaga keagungan nama tersebut. Siapa saja yang menyalahgunakannya akan dimusnahkan. Bila kemudian ada bukan Islam (Agnes) menggunakan nama ini menunjukkan Allah itu adalah Yesus, umat Islam melihatnya dari kaca mata keyakinan mereka, bukan dari kaca mata keyakinan umat Islam. Sehingga kebinekaan beragama perlu dihormati, inilah makna "bagimu agamamu dan bagiku agamaku."***

\section{Catatan Akhir}

${ }_{1}^{1}$ Muchlis M. Hanafi,Tafsir Tematik: Hubungan Antar Umat Beragama, Jakarta: Departemen Agama RI, 2008, h. xxvii.

${ }^{2} \mathrm{Abū}$ Ja'far Muḥammad bin Jarīr al-Ṭabarī, Jāmi' al-Bayān 'an Ta'wīl al-Qur'an, Cairo: Maktabah Ibn Taimiyah, t.th, h. 122.

${ }^{3} \mathrm{Abū}$ Ḥāmid al-Ghazālī, al-Maqsad al-Asnā fi Syarh Asma' Allāh alHusnā, Cairo: Dār al-Kutub al-'Ilmiyah, h. 60.

${ }^{4}$ Maḥmūd bin 'Umar bin Muhammad al-Zamakhsyarī, TafsìralKasysyāf, Jil.. 1, Cairo: Dār al-Kutub al-'Ilmiyah, 2006, h.16.

5Said Haji Ibrahim, Huraian Asma al-HusnaJalan Menuju Akidah Islam, Kuala Lumpur: Dār al-Ma'rifah, 1995, h. 6.

${ }^{6}$ Ibn Manzūr, Lisān al-'Arab, Jil.. I, Cairo: Dār al-Ma'ārif, 1995, h. 114.

72697 dengan perincian: Allahu 980, Allaha 592, Allahi 1125;

Muhammad Fuad 'Abd al-Bāqī, al-Mu'jam al-Mufahras li Alfāz al-Qur'ān al-Karim, Jakarta: Maktbah Dahlan, h. 52-96.

${ }^{8}$ Alkitab elektronik 2.0.0 (1997), Terjemahan Baru Edisi 2, Jakarta: Lembaga Alkitab Indonesia.

${ }^{9}$ Al-Kitab al-Muqaddas, Dar al-Kitab al-Muqaddas fi al-Sharq alAwsat, h. 3

${ }^{10}$ Alkitab Elektronik 2.0.0., Alkitab King James version, Alkitab contemporery English version dan Alkitab Today's English Version.

${ }^{11}$ Alkitab, Perjanjian Lama, Kejadian 1:1-3

${ }^{12}$ QS. al-Zumar[39]:3.

13Muhammad bin 'Umar Fakhr al-Dīn al-Rāzī, Asrat al-Tanzīl wa Anwār al-Ta'wīl, j. 1, Teheran: Dār al-Kutub al-Ilmiyah, t.th. h. 156.

14 al-Ghazālī, al-Maqsad, h. 60.

15Mahmūd bin 'Umar bin Muhammad al- Zamakhsyarī, TafsīralKasysyāf, Jil.. 1, Cairo: Dār al-Kutub al-'Ilmiyah, 2006, h. 36-37. 
ZAINAL ARIFIN: Kata"Allah" dalam Al-Quran dan Alkitab

16Muhammad ibn Abū Bakr, Muhammad, Badai 'al-Fawā'id Ibn Qayyim, Jil. 1., Beirūt: Dār al-Khair, 1994, h. 22.

17Ibn Manzūr, Lisān al-'Arab, Jil. I, h. 114.

18QS. al-Mu'minūn [23]: 91; Ibn Manzūr, Lisān al-'Arab, Jil. I, h. 114.

${ }^{19}$ QS. al-A'rāf [7]: 127 saat alihataka dibaca dengan ilahataka; Ibn Manzūr, Lisān al-'Arab, jil. I, h. 115.

20Ibn Manzūr, Lisān al-'Arab, Jil. I, h. 115.

${ }^{21}$ QS. al-A'rāf [7]:127 yang dibaca 'wayazaraka wa ilahataka'. Perkataan Ilahataka dalam bacaan ini adalah ganti dari perkataan Alihataka yang berarti sesembahan dan yang merupakan bacaan yang sah dan popular. Ibn Manzur, Lisān al-'Arab,Jil. I h. 115.

${ }^{22}$ QS. al-Anbiyā' [21]: 22.

${ }^{23}$ (Demikianlah wasiat Nabi Yakub, bukan sebagaimana yang kamu katakan itu wahai orang-orang Yahudi)! Kamu tiada hadir ketika Nabi Yakub hampir mati, ketika ia berkata kepada anak-anaknya: "Apakah yang akan kamu sembah sesudah aku mati?" Mereka menjawab: "Kami menyembah Tuhanmu dan Tuhan nenek moyangmu Ibrahim dan Ismail dan Ishak, iaitu Tuhan yang Maha Esa, dan kepadaNyalah sahaja kami berserah diri (dengan penuh iman)". (QS alBaqarah [2]: 133).

${ }^{24}$ Alkitab, Perjanjian Lama, Ulangan 6: 4-5, h. 200 , lihat juga Keluaran 20: 2-4, Ulangan 5: 6-9.

25"Janganlah kamu menyangka, bahwa Aku datang untuk meniadakan hukum Taurat atau kitab para nabi. Aku datang bukan untuk meniadakannya, melainkan untuk menggenapinya." Alkitab, Perjanjian Baru, Matius 5:17, h. 4.

${ }^{26}$ Alkitab, Perjanjian Baru, Markus 12:29, op.cit., h. 59, Yohanes 17:3-4, op.cit., h. 135. Lihat juga Yohanes 16:1-5, Matius 4:1-10; 10: 4042 ,

${ }^{27}$ Syaikh Muhammad Abū Zahrah, Muhāọdarat fĩ al-Kristianiyah, Cairo: Dār al-Fikr al-'Arabī, 1987, h. 125-140.

${ }^{28}$ Muhammad Ahmad Hijazī al- Saqā, al-Munaẓarah al-Hadīsah fì 'Ilm Muqaranah al-Adyān: Bayna al-Shaykh Didat wa al-Qis Suagarat, Cairo: Maktabah Zahran, 1988, h. 192-198.

${ }^{29}$ Abū Zahrah, Muḥdaarat, h. 193-194.

${ }^{30}$ Ingatlah, hanya kepunyaan Allah-lah agama yang bersih (dari syirik). Dan orang-orang yang mengambil pelindung selain Allah (berkata): "Kami tidak menyembah mereka melainkan supaya mereka 
mendekatkan kami kepada Allah dengan sedekat-dekatnya". (QS azZumar (39): 3) Lihat juga ayat 38. Lihat Shaikh Muhammad Mutawalli al-Sha'rawi (1991), Tafsir al-Sha'rawi, j. 21, Kaherah: Akhbar al-Yaum, h. 13145.

${ }^{31}$ Muchlis M. Hanafi, Tafsir Tematik, h. 213.

32Lihat buku Islam Dihujat di mana Morey menyebutkan "Allah" sebagai Dewa Bulan

${ }^{33}$ Alkitab, Perjanjian Lama, Kejadian, 1:1

${ }^{34}$ Alkitab King James Version, Genesisi, 1:1.

${ }^{35}$ Alkitab, Perjanjian Baru, Matius 1:23

${ }^{36}$ Alkitab, King James Version, Matthew 1:23

37 Alkitab, Perjanjian Lama, Keluaran.32:31

${ }^{38}$ QS. al-Zumar [39]: 3 yang telah dikutip di atas

${ }^{39}$ Oxford University, Oxford Advanced Learner's Dictionary, h. 29

${ }^{40}$ Hans Wahr, A Dictinory of Modern Written Arabic, Beirūt:

Librairie Du Liban, 1974, h. 24.

${ }^{41}$ Ensiklopedi Nasional Indonesia, Jil. I, h.270.

${ }^{42}$ WJS Purwadarminta, Kamus Umum, h. 32.

${ }^{43}$ Muhammad Farīd Wajdī, Dā'irat al-Ma'ārif al-Qarn al-'Isrīn, Beirūt: Dār al-Ma'rifah, 1971, h. 485.

44Ibn Taimiyah, Ma'rifah Allāh wa Tarīq al-Wușūl Ilaih, di-taḥqīq oleh Mușțafā Ḥilmī, Cairo: Jāmi'ah al-Qāhirah, 1995, h. 162.

${ }^{45}$ QS. Ibrāhīm [14]: 10.

46 al-Ghazālī, al-Maqsad, h. h. 50-53; Quraish Shihab, Menyingkap

Tabir Ilahi, Jakarta: Lentera Hati, 2003, h. xxvi.

${ }^{47} \mathrm{QS}$. al-Syūrā [42]: 11.

48 al-Ghazālī, al-Maqsad, h. 53.

49Ibid., h. 53-55

${ }^{50}$ QS.al-Anfal [8]:17, Allah menafikan hamba melempar, tapi Dia (Allah) yang melempar. al-Ghazālī, al-Maqsad, h. 55. Allah swt disifati dengan wajib ada, sedangkan makhluk mungkin ada.

${ }^{51}$ Quraish Shihab, Menyingkap, h. xxviii.

TEOLOGIA, VOLUME 25, NOMOR 2, JULI-DESEMBER 2014 


\section{DAFTAR PUSTAKA}

Abd al-Bāqī, Muhammad Fu'ad, al-Mu'jam al-Mufahras li Alfāẓ alQur'ān al-Karìm, Jakarta: Maktabah Dahlan, 1981.

Abū Ja'far Muḥammad bin Jarīr al-Ṭabarī, Jāmi' al-Bayān 'an Ta'wīl alQur'an, di-tahqīq oleh Muhammad Shakir (Tahqiq), Cairo: Maktabah Ibn Taimiyah, t.th.

Abū Zahrah, Syaikh Muhammad, Muḥ̣aarat fi al-Kristianiyah, Cairo: Dār al-Fikr al-'Arabī, 1987.

al-Kitāb al-Muqaddas, Dār al-Kitāb al-Muqaddas fi al-Syarq al-Awsaṭ.

Alkitab elektronik 2.0.0, Terjemahan Baru Edisi 2, Jakarta: Lembaga Alkitab Indonesia, 1997.

Alkitab Elektronik 2.0.0., Alkitab contemporery English version, Jakarta: Lembaga Alkitab Indonesia

Alkitab Elektronik 2.0.0., Alkitab King James version, Jakarta: Lembaga Alkitab Indonesia

Alkitab Elektronik 2.0.0., Alkitab Today's English Version, Jakarta: Lembaga Alkitab Indonesia

Asy'arī, Abū al-Ḥasan 'Ali bin Ismā'̄i, Maqālat al-Islāmiyīn wa Ikhtilāf al-Musallīn, Helmut Ritr (tahqiq), Beirūt: Dār al-Ihyā̄' al-Turās̀ al-'Arabì, t.th.

Baghdādī, 'Abd al-Qādir ibn Ṭāhir ibn Muḥammad, Syarh Ușūl al-Dīn, Istanbul: Mațba'ah Istanbul, 1928.

Bisatī, Aḥmad Sa'ad al-Dīn 'Ali, Muqaranah bayna al-'Aqīdatain: alYahūdiyah wa al-Islāmiyah, Cairo: Dār al-Tiba'ah al-Muhammadiyah, 1988.

Ghazālī, Abū Ḥāmid, al-Maqsad al-Asnā fi Syarh Asma' Allāh al-Husnā, Cairo: Dar al-Kutub al-'Ilmiyah, 1985.

Hanafi, Muchlis M.,Tafsir Tematik: Hubungan Antar Umat Beragama, Jakarta: Departemen Agama RI, 2008. 
Ibn Abū Bakr, Muhammad, Badai 'al-Fawā'id Ibn Qayyim, Beirūt: Dār al-Khair, 1994.

Ibn Manzūr, Lisān al-Arab, Kairo: Dār al-Ma'ārif, 1995.

Ibn Taimiyah, Ma'rifah Allāh wa Ṭarìq al-Wușūl Ilaih, di-tahqīq oleh Muștafā Hilmī, Cairo: Jāmi'ah al-Qāhirah, 1995.

Oxford Advanced Learner's Dictionary, Britanica: Oxford University Press, 1984.

Purwadarminta, W.J.S.,Kamus Umum Bahasa Indonesia, Jakarta: Balai Pustaka, 1982.

Rāzī, Muhammad bin 'Umar Fakhr al-Dīn, Asrat al-Tanzīl wa Anwār al-Ta'wìl, j. 1, Teheran: Dar al-Kutub al-Ilmiyah, t.th.

Said Haji Ibrahim, Huraian Asma al-HusnaJalan Menuju Akidah Islam, Kuala Lumpur: Dār al-Ma'rifah, 1995.

Saqa, Muhammad Ahmad Hijazī, al-Munaẓarah al-Hadīṡah fì 'Ilm Muqaranah al-Adyān: Bayna al-Shaykh Didat wa al-Qis Suagarat, Cairo: Maktabah Zahran, 1988.

Segaf, Alawy bin Abd al-Qadir, Mengungkap Kesempurnaan Sifat-Sifat Allah dalam Al-Qurandan as-Sunnah, terj. Asep Saifullah FM, M.Ag, Jakarta: Pustaka Azzam, 2001.

Shihab, Muhammad Quraish,Menyingkap Tabir Ilahi, c. 5, Jakarta: Lentera Hati, 2003.

Sya'rawi, Syaikh Muhammad Mutawalli, Tafsīr al-Sya'rawī, j. 21, Cairo: Akhbar al-Yaum, 1991.

Wahr, Hans, A Dictinory of Modern Written Arabic, Beirūt: Librairie Du Liban, 1974.

Wajdi, Muḥammad Farīd, Dā'irat al-Ma'ārif al-Qarn al-'Isrīn, Beirūt: Dār al-Ma'rifah, 1971.

Zamakhsyarī, Maḥmūd bin 'Umar bin Muḥammad, Tafsīral-Kasysyāf, jil. 1, Cairo: Dār al-Kutub al-'Ilmiyah, 2006. 